\title{
Balanço das atividades editoriais na RBG no período 2006-2012
}

No mês de maio de 2006, o então Presidente da Sociedade Brasileira de Geologia, Rômulo Machado, no início de sua segunda gestão, convidou-nos para a função de editor-chefe da Revista Brasileira de Geociências. Nesse convite colocou duas metas: periodizar a revista, recuperando um atraso de dois anos, e implantar um sistema eletrônico de submissão. Elvo Fassbinder foi convidado e passou a fazer parte do corpo editorial como editor associado, inicialmente com Clotilde Zai na secretaria, posteriormente substituída por Adriana Nascimento. O corpo editorial assim composto ficou encarregado da tramitação dos artigos; correções pré-diagramação da forma de textos e solicitações de consultores ad hoc; correções de figuras; diagramação dos números; correções das provas junto aos autores; envio dos textos originais para a editora; correções das provas da gráfica antes das impressões finais; criação das versões online com a inserção dos artigos na página da RBG; criação do acervo de números/volumes anteriores e das respostas às consultas telefônicas; e envios de e-mails para autores, consultores e leitores da RBG. Com o avolumamento dos artigos e correspondências recebidas, o corpo editorial passou a contar, a partir de outubro de 2009, com a colaboração de Carlos Eduardo de Mesquita Barros, na função de editor associado.

Desde o início das atividades se buscou atingir as metas originalmente estabelecidas para a RBG na gestão 2006-2007, presidida por Rômulo Machado. A mesma filosofia e determinação foram mantidas nas duas gestões subsequentes, de 2008-2009 e 2010-2011, presididas por Herbet Conceição. Os contatos entre SBG e PETROBRAS, iniciados na gestão de Rômulo Machado e renovados nas gestões subsequentes, garantiram recursos para a editoração, despesas de secretaria e envio dos números impressos pelo correio.

Quando os trabalhos foram iniciados pelo atual corpo editorial, os artigos eram enviados pelo correio, em duas vias, que imediatamente seguiam, também pelo correio, aos consultores $a d$ hoc, escolhidos em função do tema. Uma terceira cópia era arquivada para eventualidades de extravio ou em caso de necessidade de um terceiro parecer. O tempo de tramitação desses artigos, bem como os custos operacionais com correios, organização, acompanhamento e arquivamento, eram compreensivamente significativos.

Para a implantação do sistema eletrônico de submissão, foi escolhido o Sistema de Editoração Eletrônica de Revistas (SEER). Esse software foi especialmente desenvolvido para a construção e gestão de publicações periódicas eletrônicas, sendo coordenado no Brasil pelo Instituto Brasileiro de Informação em Ciência e Tecnologia (IBICT). O sistema contempla ações essenciais à automação das atividades de editoração de periódicos científicos. Recomendado pela CAPES, o processo editorial no SEER permite uma melhoria na avaliação da qualidade dos periódicos e uma maior rapidez no fluxo das informações.

A implantação do SEER, em junho de 2006, trouxe uma mudança radical no gerenciamento da RBG. Uma das primeiras consequências foi a agilização das submissões dos artigos e a eliminação das despesas de correio. O gerenciamento dos artigos em tramitação foi facilitada, bem como agilizada a comunicação com os pareceristas e autores. Porém, outra consequência foi o avolumamento dos trabalhos, pois, a partir de então, a RBG passou a contar, além da tradicional versão impressa, com uma nova versão eletrônica, que recebeu o número de ISSN 2177-4382, como uma mídia independente de publicação.

Após seis anos de atuação, a RBG encontra-se periodizada. O número de setembro do corrente ano (42/3) foi entregue para a editoração, o número 42(4) está em elaboração e o sistema eletrônico de submissão encontra-se em pleno funcionamento. Neste período, foram publicados 6 volumes e meio da revista (36 a 42), 26 números de circulação regular, 4 números especiais, 446 artigos com 1.556 autores e coautores, 4 notas breves com 12 autores e coautores, 12 editoriais, 6 homenagens in memoriam, 1 resenha de livro, totalizando 5.822 páginas da revista. Cabe ressaltar a importante contribuição dos editores de números especiais - Cristiane Castañeda e José Affonso Brod, no número 36(1-suplemento), com o título de "Metalogenese, Gemas e Minerais Industriais"; Aroldi Misi e Maria de Lourdes da Silva Rosa, no número 37(4-suplemento), "O Craton do São Francisco"; Saul B. Suslick, Ricardo Latge M. de Azevedo e Rogério S. de Souza, nos números 38(1-suplemento), "Geologia de reservatórios: técnicas e aplicações”, e 38(2-suplemento), "Geologia e Exploração de Petróleo"; José C. Stevaux e Edgardo M. Latrubesse, no número de circulação regular 41(4), com a edição de artigos sobre "Ambientes Fluviais". 
Consideramos que as metas colocadas por Rômulo Machado foram finalmente alcançadas, culminando com a mais ágil submissão e tramitação de artigos e com a melhor qualificação da RBG. Isto possibilitou o encaminhamento e condução do processo de indexação da RBG junto à base de dados Scopus (Elsevier), tarefa cordialmente coordenada por Mario Luis Assine. Outros pontos a serem ressaltados dizem respeito às melhorias na qualidade de editoração e impressão; mudança do layout da capa, coordenada por Rômulo Machado, em 2006; ampliação do número de consultores ad hoc de 60 para 260; controle do fluxo de artigos para consultores ad hoc por meio de planilha eletrônica com 1.450 linhas; ampliação das tradicionais áreas de publicação da RBG para Geotecnia, Geologia Ambiental, Recuperação de Museus e Patrimônios Históricos, Hidrogeologia, Geologia do Quaternário e ainda Ensino de Geociências; publicação gratuita de figuras coloridas na versão online e publicação na contracapa da revista dos geocientistas que receberam da SBG os prêmios José Bonifácio de Andrada e Silva, Martelo de Prata, Pandiá Calógeras, Henry Gorciex e Fernando Flávio Marques de Almeida.

O novo corpo editorial, liderado por Umberto Cordani, tem como meta dar um novo salto de qualidade com a desejada profissionalização, indexação na Scientific Electronic Library Online (SciELO) e internacionalização da RBG, aumentando significativamente sua visibilidade tanto a nível nacional como internacional.

Nada é conseguido sem dedicação e vontade das pessoas envolvidas. Nesse sentido, agradecemos o apoio irrestrito das gestões de Rômulo Machado, Herbet Conceição, aos consultores ad hoc, autores e do imprescindível apoio da PETROBRAS, que culminou com a elevação da RBG ao nível atual. Muito ainda haverá para ser feito, mas a motivação do atual Conselho Diretor da SBG, presidido por Moacir José Buenano Macambira (gestão 2012-2013), e do novo Corpo Editorial, certamente elevará a RBG a um nível ainda mais elevado, almejado pela comunidade geológica.

Obrigado a todos, sucesso ao atual Conselho Diretor da SBG e ao novo Corpo Editorial.

\author{
Alberto Pio Fiori \\ Elvo Fassbinder \\ Carlos Eduardo de Mesquita Barros \\ Clotilde Zai \\ Adriana Nascimento
}

